\title{
Effect Of Rgec Components ( Risk Profile, Good Corporate Governance, Earning And Capital) On Stock Returns
}

\author{
Yuliarti Rezeki ${ }^{1}$, Dyah Sri Wulandari ${ }^{2}$, Humaidi $^{3}$ \\ \{yuli.rezeki303@gmail.com ${ }^{1 *}$, dyahsriwulandari@unism.ac.id ${ }^{2}$, humaidibinsis@gmail.com ${ }^{3}$ \} \\ Department of Management Universitas Sari Mulia, Banjarmasin Indonesia ${ }^{1,2,3}$ \\ *yuli.rezeki303@gmail.com
}

\begin{abstract}
The analysis of testing used multiple linear regression analysis. The population used was banking companies listed in Indonesia Stock Exchange in the 2014-2018 period and met the criteria of sample selection. The samples used were 23 companies. Data were collected through secondary data collection in the form of company annual reports in the 2014-2018 period which were published in the Indonesia Stock Exchange. The research hypothesis was tested by multiple linear regression that has met the classical assumption test. The result of the analysis shows that Non-Performing Loans, Interest Rate Risk, Loan to Deposit Ratio, Return on Assets have no significant effect on stock returns while Capital Adequacy Ratio, Institutional Ownership, have a significant effect on stock returns
\end{abstract}

Keywords: RGEC Components, Non-Performing Loans, Interest Rate Risk, Loan to Deposit Ratio, Institutional Ownership, Return on Assets, Capital Adequacy Ratio, Stock Return.

\section{Introduction}

Banks are one of the most important industries in the Indonesian economy. Banking mediates between people who have excess funds and people who need funds. Banks in business should always me ngedepankan customer confidence, w equivalent of k epercayaan these clients is to ensure the smooth operation of the right of return will be accepted by the customer appropriately and in accordance with the agreement that has been agreed by both parties. Banks with low liquidity or bad returns will have a negative impact on the survival of banks and the economic conditions of a country.

There are several economic situations in Indonesia where the impact was felt not only on banks but also the state of the country at the time. The condition is k RISIS global financial happened in the United States have an impact on developing countries including Indonesia in 2008 . The global financial crisis caused a banking crisis. Weakening exchange rates of several countries E merging Markets in 2013.

The weakening of the exchange rate can lead to decreased liquidity and if this is not anticipated to quickly feared the higher NPL ratio membahay and will certainly be the performance of the bank. Poor economic conditions due to the global crisis make banks must 
be more sensitive to economic situations and conditions that are less supportive, there must be a measurement or parameters used as a reference to assess the performance of the bank to the fullest, so that banks can run healthily .

The bank soundness method is an important aspect that must be known by the bank and its stakeholders. The level of soundness of a bank does not only reflect the financial performance of banks, but also can reflect the performance of bank management. The higher level of health of banks will berpenga $\mathrm{r}$ uh in return shares generated. Rate the level of health of the bank consists of RGEC (Risk Profile, Good Corporate Governance, Earnings, Capital ), where s ach component of RGEC is ra s io finance and corporate governance.

\section{Formulation of the problem}

Does the Non Performing Loan (NPL) negatively affect stock returns. (2) Does the Interest Rate Risk (IRR) negatively affect stock returns. (3) Does the potentially negative Loan To Deposit Ratio (LDR) (4) Does Institutional Ownership (KI)have a positive influence on stock returns. (5) Does Return on Assets (ROA) have a positive effect on stock returns. (6) Does the Capital Adequacy Ratio (CAR) have a positive effect on stock returns

\section{Research purposes}

In accordance with the formulation of the problem, the purpose of this study is u ntuk analyze the effect of non-performing loan (NPL), Interest Rate Risk (IRR), Loan to Deposit Ratio (LDR), Kepemilikan Institutional (KI), Return on Assets (ROA), and Capital Adequacy Ratio (CAR) on banking sector stock returns .

\section{Research Methods}

\subsection{Types of research}

This type of research in this paper is a type of causal research, which aims to analyze the Effect of RGEC Components ( Risk Profile, Good Corporate Governance, Earning, Capital ) Against Stock Returns in the Banking Sector Study on the Indonesia Stock Exchange, the observation period from $2014-2018$.

\subsection{Population and sample size}

The population in the study amounted to 42 banking companies listed on the Indonesia Stock Exchange during the study period, namely 2014-2018. The method used to determine the sample is a purposive sampling method, where the sample of the company is chosen based on certain criteria in accordance with the objectives. The criteria used to select a sample are as follows:

1. Banks listed (listed) on the Stock Exchange for the period 2014-2018

2. A new banking company listed (listing) on the Stock Exchange over the period 2014

3. Banking companies experiencing delisting

4. Banking companies that experienced a merger

5. Banking companies that do splite

6. Banking companies whose financial performance (ROA) is negative.

The dependent variable in this study is stock returns. The independent variable in this study consisted of: Non-Performing Loan (NPL), Interest Rate Risk (IRR), Loan to Deposit 
Ratio (LDR ), Owners' I nstitusional (KI), Return on Assets (ROA), and the Capital Adequacy Ratio ( CAR). F ungsional independent variables on the dependent variable may be formulated in a multiple regression model, as follows:

$$
\mathrm{Y}=\alpha+\mathrm{b}+\mathrm{X} 1+\mathrm{b} 2 \mathrm{X} 2+\mathrm{b} 3 \mathrm{X} 3+\mathrm{b} 4 \mathrm{X} 4+\mathrm{b} 5 \mathrm{X} 5+\mathrm{b} 6 \mathrm{X} 6+\mathrm{e}
$$

Information:

$\mathrm{Y}:$ The dependent variable is Stock Return

$\mathrm{X}_{1}$ : Non Performing Loans (NPL)

$\mathrm{X}_{2}$ : Interest Rate Risk (IRR)

$\mathrm{X}_{3}$ : Loan to Deposit ratio (LDR)

$\mathrm{X}_{4}$ : Ownership of Institution 1 (KI)

$\mathrm{X}_{5}$ : Return On Asset (ROA)

$\mathrm{X}_{6}$ : Capital Adequacy Ratio (CAR).

$\alpha$ : Constants

$\mathrm{b}_{1}, \mathrm{~b}_{2}, \mathrm{~b}_{3}, \mathrm{~b}_{4}, \mathrm{~b}_{5}, \mathrm{~b}_{6}$, : Coefficient Recourse i

e: standard error or error

\section{Research Results and Discussion}

As it is known the number of samples are 42 companies and which meet kri Teria sample of 23 companies with the amount of data as much as 115 , but at the time there was a regression of the data 15 outl i er to be incurred in order to meet the assumption of normality. The number of samples digun a right after the test outlier as many as 100 data.

\subsection{Descriptive statistics}

Based on calculations performed on each of the variables studied, a Descriptive Statistics was obtained, as follows:

Table 1

Descriptive Statistics

\begin{tabular}{lrrrrr}
\hline & N & Minimum & \multicolumn{1}{c}{ Maximum } & \multicolumn{1}{c}{ The mean } & \multicolumn{1}{c}{ Std. Deviation } \\
\hline NPL & 115 &, 21 & 302.00 & 11,1743 & 45.50731 \\
IRR & 115 & 73.31 & 10681.00 & 201.4615 & 985,85087 \\
LDR & 115 & 44.24 & 8846.00 & 304,6719 & 1356,89090 \\
KI & 115 & 17.00 & 99.00 & 71,2957 & 25,32143 \\
ROA & 115 &, 20 & 357.00 & 44.9350 & 80,64516 \\
CAR & 115 & 11.67 & 2013.00 & 159,6164 & 450,90726 \\
RETURN & 115 & $-46,14$ & 670.00 & 10,9557 & 72,90853 \\
Valid N (listwise) & 115 & & & & \\
\hline
\end{tabular}

Source: SPSS results, data processed 2019

\subsection{Classic assumption test}


Before a regression analysis is carried out there are a number of classic assumptions that must be met. The classic assumption test aims to get the results of the estimation of the regression parameters to get a value that is BLUE ( Best Linear Unlimited Estimation ) so that the conclusions obtained are correct. The researcher transformed the data after conducting an outlier test because there was an assumption test of autocorrelation that could not be fulfilled. Researchers treated the The Cochrane-Orcutt method. The Cochrane-Orcutt method is in accordance with Ghozali (2013: 123).

\subsection{Normality test}

Value Kolmogorov-Smirnov on regression of 0,01,2. The data is normally distributed and meets the normality test. The value of 0,012 is obtained after data transformation. The results of the normal mality test are shown in table 2 below:

Table 2. One-Sample Kolmogorov-Smirnov Test

\begin{tabular}{llr}
\hline & & Unstandardized Predicted Value \\
\hline $\mathrm{N}$ & & 100 \\
Normal Parameters a, b & The mean & 1,1708764 \\
& Std. Deviation & 13.05751308 \\
Most Extreme Differences & Absolute &, 102 \\
& Positive &, 074 \\
Statistical Test & Negative & -102 \\
Asymp. Sig. (2-tailed) & &, 102 \\
a. Test distribution is Normal. & &, $012^{c}$ \\
b. Calculated from data. & & \\
c. Lilliefors Significance Correction. & \\
\hline
\end{tabular}

\subsection{Multiplicity Test nieritas}

Results uj $\mathrm{i}$ assumptions multicollinierity in value by looking at the value of VIF (Variance Infloating Factor) on each variable and the results stated that the independent variable has a value of less than $10 \mathrm{o}$ leh therefore concluded that the data used are not correlated and Asums i multikolinieritas fulfilled. The test results assuming $\mathrm{m}$ ultikolinieritas can be seen in Table 3 below:

Table 3. Multicollinearity Assumption Test 


\begin{tabular}{cccl}
\hline Independent variable & Tolerance & VIF & Information \\
\hline LAG X1 @ &, 948 & 1,055 & Multicollinearity free \\
LAG X2 @ &, 908 & 1,101 & Multicollinearity free \\
LAG X3 @ &, 967 & 1,035 & Multicollinearity free \\
LAG X4 @ &, 942 & 1,062 & Multicollinearity free \\
LAG X5 @ &, 908 & 1,101 & Multicollinearity free \\
LAG X6 @ &, 943 & 1,060 & Multicollinearity free \\
\hline
\end{tabular}

Source: SPSS results, data processed 2019

\subsection{Autocorrelation Test}

Results uj i assumptions autocorrelation in value by looking at the value of the DurbinWatson amounted to 1,917 . This value is then compared with the DU table value, where $\mathrm{k}=$ 6 and $\mathrm{n}=100$ (after transformation). DU is 1.8031 and the value (4-dU) is 2.1969 , so the value of D U <DW <4- D U is $1.8031<1,917<2.1969$ so it can be concluded that there is no problem of autocorrelation and assumptions are accepted. The results of the a utocorrelation assumption test can be seen in the following table 4:

Table 4. Autocorrelation Assumption Test Summary Model ${ }^{\mathrm{b}}$

Model
$\begin{aligned} & \text { R } \\ & 1\end{aligned}$

\subsection{Heterokedasticity Test}

Based on the results of the test heterokedastisitas can be seen that all independent variables are variables NPL (LagX1@), IRR (LagX2@), LDR (LagX3@), KI (lagX4@), ROA (LagX $5 @$ ), and CAR (LagX $6 @$ ) has a significance value (probability) $>\alpha=0.05$ and it is decided to accept Ho. This shows that the data used does not occur in the case of heteroscedasticity so that this assumption has been fulfilled as shown in table 5 below:

Table 5 Heteroscedasticity Test Coefficients $^{\text {a }}$ 


\begin{tabular}{|c|c|c|c|c|c|c|}
\hline & \multirow[t]{2}{*}{ Model } & \multicolumn{2}{|c|}{ Unstandardized Coefficients } & \multirow{2}{*}{$\begin{array}{c}\begin{array}{c}\text { Standardized } \\
\text { Coefficients }\end{array} \\
\text { Beta }\end{array}$} & \multirow[b]{2}{*}{$\mathrm{t}$} & \multirow[b]{2}{*}{ Sig. } \\
\hline & & $\mathrm{B}$ & Std. Error & & & \\
\hline \multirow[t]{7}{*}{1} & (Constant) & 14,962 & 3,961 & & 3,777 &, 000 \\
\hline & LAGX1@ & $-1,643$ &, 959 & -169 & $-1,714$ &, 090 \\
\hline & LAGX2@ & -121 & 088 & -137 & $-1,365$ &, 176 \\
\hline & LAGX3 @ &, 122 &, 091 &, 131 & 1,339 &, 184 \\
\hline & LAGX4@ &,- 168 &, 066 & -250 & $-2,532$ &, 130 \\
\hline & LAGX5 @ & 015 &, 022 &, 067 &, 669 & 505 \\
\hline & LAGX6@ @ &,- 083 &, 301 &,- 027 & -275 &, 784 \\
\hline
\end{tabular}

a. Dependent Variable: ABS_RES3

\subsection{Model Feasibility Testing (F Test)}

Based on the ANOVA test or F test, the calculated value is 2.277 with a probability of 0.043 , because the probability or significance level is smaller than $\alpha=5 \%$, it can be said that the NPL, IRR, LDR, KI, ROA variables and CAR simultaneously (simultaneously) significantly influence the stock return variable, so that the model can be accepted, it can be seen in table 6 below:

Table 6 Model Feasibility Testing (Test F)

\section{ANOVA a}

\begin{tabular}{|c|c|c|c|c|c|c|c|}
\hline \multirow{3}{*}{$\begin{array}{l}\text { Model } \\
1\end{array}$} & \multirow[b]{3}{*}{ Regression } & \multirow{3}{*}{$\begin{array}{r}\text { Sum of Squares } \\
16879,366\end{array}$} & \multicolumn{4}{|c|}{ Mean } & \multirow{3}{*}{$\begin{array}{l}\text { Sig. } \\
, 043^{b}\end{array}$} \\
\hline & & & $\mathrm{df}$ & & Square & $\mathrm{F}$ & \\
\hline & & & & 6 & 2813,228 & 2,277 & \\
\hline & Residual & 114886,034 & & 93 & 1235,334 & & \\
\hline & Total & 131765,400 & & 99 & & & \\
\hline
\end{tabular}

a. Dependent Variable: LAGY @

b. Predictors: (Constant), LAGX6 @, LAGX1 @, LAGX5 @, LAGX3 @, LAGX4 @,

LAGX2 @

\subsection{Hypothesis Testing ( $t$ test)}

Table 7. Partial Hypothesis Testing

Coefficients ${ }^{\text {a }}$

\begin{tabular}{|c|c|c|c|c|c|c|}
\hline \multirow{2}{*}{\multicolumn{2}{|c|}{ Model }} & \multicolumn{2}{|c|}{$\begin{array}{l}\text { Unstandardized } \\
\text { Coefficients }\end{array}$} & \multirow{2}{*}{$\begin{array}{c}\begin{array}{c}\text { Standardized } \\
\text { Coefficients }\end{array} \\
\text { Beta }\end{array}$} & \multirow[b]{2}{*}{$\mathrm{t}$} & \multirow[b]{2}{*}{ Sig. } \\
\hline & & $\mathrm{B}$ & Std. Error & & & \\
\hline 1 & (Constant) & 3,998 & 16,129 & &, 248 &, 805 \\
\hline & LAGX1@ & 1,512 & 3,904 &, 039 &, 387 &, 699 \\
\hline & LAGX2@ &, 073 &, 360 &, 021 &, 203 &, 840 \\
\hline & LAGX3@ & -240 &, 371 &,- 064 & -648 &, 519 \\
\hline & LAGX4@ & -657 &, 270 &,- 243 & $-2,433$ &, 017 \\
\hline & LAGX5 @ &, 033 &, 089 & , 038 &, 370 &, 713 \\
\hline & LAGX6 @ & 2,659 & 1,226 &, 216 & 2,169 &, 033 \\
\hline
\end{tabular}


a. Dependent Variable: LAGY @

Based on Table 7 shows that :

1. The significant value of $\operatorname{LagX} 1$ @ is 0.699 , the value is greater than 0.05 . so it can be said that LagX1@ (NPL) has no effect on stock returns. Then H1 was rejected .

2. The significant value of $\operatorname{LagX} 2$ @ is 0.840 , the value is greater than 0.05 . so it can be said that LagX 2 @ ( IRR ) has no effect on stock returns. Then $\mathbf{H} 2$ is rejected .

3. The significant value of $\operatorname{LagX} 3$ @ is 0.519 , the value is greater than 0.05 . so it can be said that LagX 3 @ (L DR ) has no effect on stock returns. Then $\mathbf{H} 3$ rejected .

4. The significant value of $\operatorname{LagX} 4$ @ is 0.17 , the value is smaller than 0.05 . so it can be said that LagX 4 ( KI ) has a significant negative effect on stock returns. Then $\mathrm{H} 4$ in receiving.

5. The significant value of $\operatorname{LagX} 5$ @ is 0.713 , the value is greater than 0.05 so it can be said that LagX 5 @ ( ROA ) has no effect on stock returns. Then H 5 is rejected

6. The significant value of LagX 6 @ is 0.33 , the value is smaller than 0.05 . so it can be said that LagX6@ ( C A R ) has a significant positive effect on stock returns. Then $\mathrm{H} 6$ in receiving.

\subsection{Analysis of the Coefficient of Determination}

Table 8. Determination Coefficient Value Summary Model ${ }^{b}$

\begin{tabular}{|l|c|r|r|r|}
\hline Model & $\mathrm{R}$ & R Square & Adjusted R Square & Std. Error of the Estimate \\
\hline 1 &, $358^{\mathrm{a}}$ &, 128 &, 072 & 35,14731 \\
\hline
\end{tabular}

a. Predictors: (Constant), LAGX6 @, LAGX1 @, LAGX5 @, LAGX3 @, LAGX4 @, LAGX2@

b. Dependent Variable: LAGY@

The coefficient d eterminasi $\left(\mathrm{R}^{2}\right)$ is used to determine the contribution of use of independent variables in explaining the dependent variable. Determination coefficient table Table 8 above, it can be seen that the correlation coefficient $(\mathrm{R})$ of 0,358 . The coefficient of determination (Adjusted R square) is 0.072 or $7.2 \%$. This shows that the variables NPL (LagX1@), IRR (LagX2@), LDR (LagX3 @), KI (lagX4@), ROA (LagX 5 @), and CAR (LagX6@) are only able to affect the re turn s value aham (Y) of 7, 2\%, while the remaining $92,8 \%$ is influenced by other variables outside the study.

\section{Research Limitations}

a. The scope of the research is limited to banking sector companies so the results of this study cannot be identified in companies listed on the Indonesia Stock Exchange.

b. The variables used in this study are limited, while there are many other variables that represent the RGEC component.

c. Components for market risk can use Net Open Position, for liquidity risk you can use a variable that is Loan to Funding Ratio. The GCG component can add managerial ownership, Board of Directors Size, Audit Committee and Board of Commissioners Proportion. Earning component can be added with ROE ( Return on Equity ). 


\section{Conclusion}

The results of the research can be summarized as follows:

a. Statistical test results show that the NPL, IRR, LDR, KI, ROA, and CAR variables together have an influence on stock returns. The results of the statistical test show that the variables KI and C A R are partially sig. on stock returns .

b. NPL has no significant effect, the significance of this NPL is due to the slowing down of Indonesia's economy. This has an impact on the slowing pace of bank credit. NPLs can continue to increase if they are not always monitored and monitored, which will have another impact, namely the drop in commodity prices and the slow pace of infrastructure development.

c. Interest Rate Risk variable is not significant on stock returns. The significance of this research is due to Indonesia's slowing economic conditions. The economic slowdown could have an impact on the weakening of the rupiah.

d. Loan to Deposit variable ratio is not significant on stock returns. LDR does not affect stock returns because banks do not use LDR as a basis for consideration in making decisions to channel funds in credit, so it does not affect the ups and downs of returns to banks.

e. The Return On Asset variable is not significant to stock returns, where the ROA ratio is used to measure the ability of management to obtain net benefits from the use of assets. This study shows that there is no effect of ROA on stock returns. This means that management cannot use the maximum total assets (current assets and fixed assets) and in the end cannot increase stock returns .

\section{Suggestion}

a. The results of this study are expected to provide wawa sa $\mathrm{n}$ for management and investors in analyzing the performance of perusa pany. Given the ownership structure becomes an important part in agency theory because most agency conflicts are caused by the separation of ownership from the manager.

b. Capital Adequancy Ratio (CAR) has a positive and significant effect on Stock Returns . This is consistent with the theory that the higher the CAR, the more solvable the bank. Banks that have a high CAR, means the bank has sufficient capital to run its business so that it will increase profits. A high Capital Adequacy Ratio (CAR) means that banks have the ability to overcome possible losses due to credit and trade in securities. In addition, the public and investors will believe in the ability of bank capital and funds absorbed from the community to increase which will ultimately increase stock returns

c. For future researchers, it is expected that future research will further examine the banking system as a whole in its performance of the banking world itself and the economy in general so that the expected results can be more accurate.

\section{References}


[1] Ahmadi and Safarzadeh, 2015, Evaluation of the Impact of Corporate Governance Components on the Relationship between Earnings Management and the Financial Performance of the Companies Listed in the Tehran Stock Exchange . UMP Journal of Social Sciences and Technology Management Vol. 3, Issue.3,2015.http: //jsstmump.org/2015\%20Volume\%203,\%20Issu e\% 203 / 29-48.pdf [3 February 2019 ]

[2] Azeem and Amara (2014) Impact of Profitability on Quantum of Non-Performing Loans. International Journal of Research \& Development in Technology and Management Science --ailash Volume - 21 | Issue 1 | ISBN - 978-1-63102-445-0 | March 2014 editor.ijrdtm@rtmonline.in | editor@ijrdtm.com | http://journal.rtmonline.in | http://www.ijrdtm.com [April 2, 2019]

[3] Bank Indonesia 2011, Bank Indonesia Regulation No. 13/1 / PBI / 2011 dated January 15, 2011, Rating of Commercial Banks , Jakarta.

[4] Bank Indonesia 2011, Circular Letter No 13/24 / DPNP dated 25 October 2011, Rating of Soundness of Commercial Banks, Jakarta.

[5] Bank Indonesia 20013, Circular Letter No 15/15 / DPNP / 2013, Implementation of Good Corporate Governance for Commercial Banks. Jakarta

[6] Candradewi, Intan and Sedana, Ida Bagus Panji 2016 Effects of Managerial Ownership, Institutional Ownership and Independent Board of Commissioners on Return on Assets. Eud Management Journal, Vol. 5, No. 5, 2016: 3163 - 3190 ISSN: 2302-8912. , http: //download.portalgaruda.org/article.php? article $=411596 \&$ val $=989 \&$ title $=$ EFFECTS $\%$ 20MINEMENITY\% 20MINERIAL, $\% \quad 20$ OWNERSHIP\% 2OINSTITUTIONAL $\% \quad$ 20DAN\% 20DEWAN\% 20COMMISSION\% 20INDEPENDENT\% 20MINERIAL [April 2, 2019]

[7] Chuang, Hongwei 2015, Institutional Ownership and Stock Returns , http://www.econ.tohoku.ac.jp/econ/datascience/DDSR-DP/no47.pdf [ 2 April 2019]

[8] Damayanti and Susanto (2015) Effects of Audit Committees, Audit Quality, Institutional Ownership, Company Risk and Return On Assets Against TAX Avoidance. Vol.5, No.2, October 2015. Essence. Business Journal and management. http://repository.uinjkt.ac.id/dspace/bitstream/123456789/31250/1/Fitri\%2 ODamayanti\%20dkk.pdf . [2 2 April 2019]

[9] Dewi, Putu AR, et al, 2016. Peng aruh Interest Rates, Risk Markets, Debt To Equity Ratio and Price Earning Ratio Against Return Shares in Property Companies And Real Estate in the Indonesia Stock Exchange. ISSN: 2337-3067 E-Journal of Economics and Business of Udayana University 5.3 (2016): 489516 http://ojs.unud.ac.id/index.php/EEB/article/download/16056/13328[4 July 2019 ]

[10] Gantino, Rilla and Fahri Maulana, Fahri, 2013, The Effect of Roa, Car, and Ldr on Stock Returns on Banking Companies Listed on the Indonesia Stock Exchange Period 20082012, http://jp.feb.unsoed.ac.id/index. php / sca-1 / article / viewFile / 308/313 [2 2 April 2019]

[11] Hanafi, Mamduh M, 2014, Financial Management, Issue 1, BPFE. Yogyakarta

[12] Hanum, Zulian, 2015, The Effect of Return on Assets (Roe), Return On Equity (Roe), and Earning Per Share (Eps) Against Stock Prices on Automotive Companies Listed on the Indonesia Stock Exchange Period 2008-2011 . Journal of Management \& Business, ISSN: $\quad 1693-7619, \quad$ Vol $\quad 08 \quad 1002$ April 2009, http://jurnal.umsu.ac.id/index.php/kumpulandosen/article/download/301/pdf 22, [22 April 2019] 
[13] Hendrayana, PW \& Yasa GW, 2015. Effects of RGEC Components on Changes in Banking Company Stock Prices on the Indonesia Stock Exchange. ISSN: 2302-8556, EJournal of Accounting at Udayana University 11.1 (2015): 74-89, [ 23 April 2019 ]

[14] Heydari and Abdoli, 2015, The Effect of Credit Risk Management and Capital Adequacy on Financial Performance of Business Banks. Indian Journal of Science and Technology, Vol 8 (S8), 196-200, April 2015 , [2 2 April 2019]

[15] Hidayati, Yuvia, 2015. Effect of Capital Adequacy Ratio (Car), Net Interest Margin (NIM), Loan To Deposit Ratio (Ldr) and Non Performing Loans (Npl) Against Return On Assets (Roa) At Pank Pand (Persero). Tbk http://journal.ubb.ac.id/index.php/holistic/article/download/299/222 , [September 29, 2019]

[16] IBI and BARA 2015a, Risk Management 1, Publisher of PT.Gramedia Pustaka Utama.Jakarta

[17] Indian, Goddess, 2016 . The Influence of Bank Health Level Variables on Banking Stock Prices on the Indonesia Stock Exchange . Eud Management Journal, Vol. 5, No. 5, 2016: 2756 - 2785, ISSN: 2302-8912 [1 2 April 2019]

[18] Latief, Rashid, 2014. Impact of Corporate Governance on Performance of Privatized Firm Evidence from the Non-Financial Sector of Pakistan, Middle-East Journal of Scientific Research 19 (3): 360-366, 2014 ISSN 1990-9233 @ IDOSI Publications, 2014 , $\quad$ DOI: $\quad 10.5829$ idosi.mejsr.2014.19.3.13607 http://www.idosi.org/mejsr/mejsr19(3)14/7.pdf, April 2019 ]

[19] Matindas, Anggria Maya, et al 2015 , Effects of Capital Adequacy Ratio (Car), Bopo and Non Performing Loans (Npl) on Financial Performance of Banking in Indonesia . http://ejournal.unsrat.ac.id/index.php/gc/article/view/7367[6[6 [ 2 April 2019 ]

[20] Mahilo, michael B and Parengkuan, Tommy, 2015, Impact of Interest Rate Risk, Inflation, and Exchange Rates Against Stock Returns of Food and Beverage Companies that Go Public on the Indonesia Stock Exchange, ISSN 2303-1174

[21] Monica, Genoveva, 2016, The Effect of Profitability, Capital Strength, Credit Growth on the Stock Prices of Registered Banking Companies in Business 27 http://ejournal.unesa.ac.id/article/18741/57/article.pdf [ 23 April 2019 ] 